\section{6lib Prof. J. Velenovsky}

THF death occurred May 7 of the Czechoslovak botanist, Prof. Jose Welenovsky, at Mnichovice, near Prague; he way hinety-one years of age.

Born at okanice, a small southern Bohemian village, on April 22,1858 , Velenovský was a student of Sads sard Celakovský, and in 1885 he obtained a pat at the Charles University of Prague. In 1898 he succeeded Celakovský as professor and continued teaching for forty-two years until he retired in 1927. It was during his professorship that the present Botanical Institute was erected, and for many years Velenovsky was also director of the botanical gardens attached to the Institute.

During his career he wrote at least four hundred different publications, including a number of textbooks and treatises that served successive generations of Czech students. His early researches related to phytopalæontology, especially the fossil flowering plants occurring in Bohemian chalk (1882-87). His studies in this field were published in a work of five volumes, "Flora Cretacea Bohemiæ".
June 1I, 1949 Vol. 163

Later, Velenovský made a detailed systematic study of fungi, and he is probably best known in Great Britain for his "Ceské Houby" (Bohemian Fungi), first published between 1922 and 1926 and revised in 1946. The book is noteworthy for its illustrations. He spent many vacations in the Balkans, and one outcome was his "Flora Bulgarica" (1891), the standard flora for the country and which he afterwards brought up to date with addenda. Later work was mainly concerned with studies of the bryophytes (1897), though he contributed to many branches of systematic botany, and as late as 1947 he was engaged upon "Novitates Mycologicæ Novissimæ", which is being published by the Czechoslovak Botanical Society.

After retiring, Velenovský maintained his scientific interests and also wrote some philosophical and historical essays. One of these was for the jubilee publication in 1932 of the Czech Naturalists' Club, of which he was the oldest living member. Velenovský received many Continental and some British honours.
J. G. F. D.

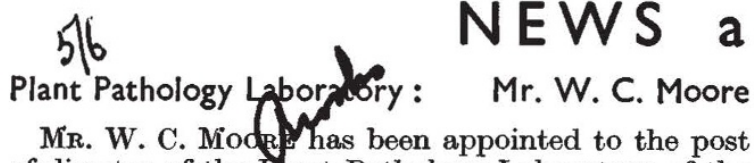
of director of the Plant Pathology Laboratory of the Ministry of griculture and Fisheries at Harpenden, on the retre nent of Mir. C. T. Gimingham. Mir. Mopre recoived his early education at Sexey's School, Brfte whence he joined Trinity College, Cambridge, in 615, becoming a major scholar in 1921. After graduation he remained at the Cambridge Botany School to participate in the investigations on silverleaf disease of fruit trees then in progress. He joined the staff of the Plant Pathology Laboratory in 1925 as assistant in mycology, becoming mycologist in 1944 and deputy director in 1948. During his official career he has been in the closest touch with other British plant pathologists, especially those in the advisory services, whose work he has greatly fostered and assisted. Not infrequently he has suggested problems for investigation. Latterly, he has been responsible for editing a series of valuable reports on the incidence of plant diseases in England and Wales. He has taken a principal part in preparing the excellent leaflets on the diseases of economic plants issued by the Ministry. Notwithstanding heavy administrative duties he has continued his own re. searches (chiefly on little-known diseases), the results of which have been mostly published in the Trans. actions of the British Mycological Society. Noteworthy, too, is his bulletin on the "Diseases of Bulbs", published in 1939, which is an important contribution to plant pathological literature. He was president of the British Mycological Society in 1941 and of the Association of Applied Biologists in 1947-48. Mir. Moore is a keen gardener, and the practice of this art has been not without influence on his career as a plant pathologist.

\section{Geology at Sheffield: Prof. Leslie R. Moore}

DR. LEgLIE R. Mooke, at present reader in stratigrayny in the University of Bristol, has been appoinled to the Sorby chair of geology in the University of Sheffield, in succession to Prof. F. W.
Shotton (see Nature, 155, 664 ; 1945), who has been appointed to the chair of geology at Birmingham. It is expected that Prof. Moore will take up his duties at the opening of the new session in October next. After taking his first degree at the University of Bristol in 1934, Dr. Moore carried out postgraduate work on "The Sequence and Structure of the Somerset and Gloucestershire Coalfields", for which he was awarded the Ph.D. degree. His first university appointment was in the Department of Geology, University College, Cardiff ; later he became research fellow and lecturer in geology in the University of Glasgow, before returning to Bristol as reader in stratigraphy. Dr. Moore's researches have dealt especially with the geology of coal measures and oil shales and are notable for the employment of new techniques, to the development of which he himself has made substantial contributions.

\section{New Grassland Research Station at Hurley: Dr. W. Davies}

Dr. William Davies, at present director of the Grassland Improvement Station of the Ministry of Agricyture and Fisheries at Drayton, Stratford. on-Aym, has been appointed director of the Grassland Regearch Station for Great Britain. This new station is being established at Hurley in Berkshire and is being amalgamated with the Drayton Station under the new Governing Body, the formation of which was recently announced. Dr. Davies was a student at the University College, Aberystwyth, under Sir George Stapledon, and was later a member of stafi at the Welsh Plant Breeding Station at Aberystwyth. On the establishment of the Grassland Improvement Station, he was appointed assistant director, and became director in 1946 on the resignation of Sir George Stapledon. Dr. Davies has conducted researches and surveys in New Zealand, Australia and the Argentine. A survey of the grasslands of England was made in the years $1938-10$, and the results were published in 1941 . More recently, Dr. Davies has visited several African countries and carried out grassland surveys there. 